\title{
IMPACT OF IGNEOUS ROCK ADMIXTURES ON GEOTECHNICAL PROPERTIES OF LIME STABILIZED CLAY
}

\author{
Syed Husnain Ali SHAH ${ }^{1,2,{ }^{*}, \text { Muhammad ARIF }}{ }^{3}$, Mohammad Amjad SABIR ${ }^{2}$, Qasim \\ ur REHMAN ${ }^{4}$ \\ ${ }^{1}$ Department of Geology, Hazara University, Mansehra, Pakistan. \\ 2 Department of Earth Sciences, COMSATS University Islamabad, Abbottabad, Pakistan. \\ ${ }^{3}$ Department of Geology, University of Peshawar, Peshawar, Pakistan. \\ ${ }^{4}$ Department of Earth Sciences, University of Haripur, Haripur, Pakistan. \\ corresponding author: shas.husnain@gmail.com.
}

\section{Abstract}

This paper investigates the probable influence of powder from two igneous rocks, namely granite and rhyolite, on the geotechnical properties of lime stabilized clay soil. A clay soil sample was collected from Jhelum, city of the province Punjab in Pakistan, and its major geotechnical properties including particle size distribution, Atterberg limits, Activity, compaction parameters, California Bearing Ratio (CBR) and unconfined compressive strength (UCS) were determined by using standard ASTM procedures. Owing to the presence of clay minerals, the Jhelum soil is classified as $\mathrm{CH}$ soil (Fat clays) following the Unified classification system. Lime was added to the soil in the range of $0-12 \%$ and the most influential lime percentage, i.e. the one causing the highest possible positive impact on geotechnical properties, was chosen for further stabilization. Following a gradual increase by $8 \%$, up to $32 \%$ of granite and rhyolite powders were separately mixed with the soil sample showing maximum stabilization with lime, i.e. the sample containing $6 \%$ lime. Each of the resulting samples was tested for all the parameters mentioned above. The results demonstrate that addition of granite and rhyolite powders produces significant improvement in workability and performance of the clay soil previously stabilized with $6 \%$ lime. The improvement is obvious from reduction in Plasticity index, Activity and optimum moisture content, and rapid increase in UCS, maximum dry density and CBR. The principal reason for the observed positive changes is the presence of abundant non-active and denser minerals in granite and rhyolite powders as compared to lime and clay soil. Furthermore, the positive impact of rhyolite on the geotechnical behaviour of soil is relatively higher than granite obviously because of its better petrographic features, physical properties and strength.
\end{abstract}

\section{Keywords:}

Compaction parameters;

Atterberg limits;

Unconfined Compressive Strength; California Bearing Ratio.

\section{Introduction}

Clay soils, also known as active soils, undergo heavy volume changes since their clay mineral content make them absorb high amount of water. The expansive nature of clay minerals is primarily linked with geology, engineering characteristics of soil and environmental conditions of the local area $[1,2]$. The behaviour of clay soils changes with the amount of moisture and the energy with which it is retained $[3,4]$. These soils typically have the potential to exhibit detrimental geotechnical properties, such as low strength, shrinkage, high settlement and swelling characteristics as well as high water vulnerability [5]. Stabilization of such soils through various admixtures is currently in practice since their replacement with other materials, e.g. gravel and light weight aggregates or utilization of other ground improvement alternatives including stone columns, grouting or wick drains with good quality soils, is very costly $[6,7]$. Cement also is no longer considered as an ideal choice for soil stabilization 
due to high cost and environmental concerns related to its production [7]. The most important admixture commonly used nowadays for soil stabilization is a variety of lime, e.g. high-calcium hydrated lime, calcite lime, mono hydrated dolomitic lime and dolomitic quicklime. Several important geotechnical properties of clayey soils can be beneficially modified by this treatment, since lime is known to decrease the plasticity index $(\mathrm{PI})$, increase workability, shrinkage limit, strength and $\mathrm{CBR}$, and eliminate almost all swelling problems $[8,5]$.

Extensive studies are available on the stabilization of clayey soils with lime [9-16]. However, the effects of lime admixture on soil stabilization appear to be limited. According to Bell [9], the best possible amount to be added for utmost stabilization of soil is $1-3 \%$ lime, beyond which the Atterberg limits do not change. According to Basma and Tuncer [17] and Swadaniet al. [7], the maximum lime content that can positively modify soil properties is $2-8 \%$ and $4 \%$, respectively. Keeping in view these results, researchers are now conducting studies to identify an admixture(s) that can be effectively utilized for stabilizing a lime-stabilized soil further. Khalid et al. [18] and Saeed [19 etc...] used Pofa and Zeolite respectively for additional improvement of lime stabilized clay. The current study is planned to analyze and assess the possible influence of powder addition from two igneous rocks, granite and rhyolite, on the geotechnical properties of lime stabilized clay. For this purpose, different proportions of the two rock powders were used as stabilization agents in an initially lime stabilized soil.

\section{Materials}

\subsection{Soil}

A sample of dominantly clay soil was collected from Jhelum, which is a part of the Punjab province in Pakistan (Fig.1). The soil sample was extracted from a depth of one meter. Different laboratory tests were conducted to properly classify the soil. Results from grain size distribution test show that $62.4 \%$ of the soil sample consists of material finer than \#200 mesh (Fig. 2). Hydrometer analysis was carried out using the ASTM 5120 method [20]. The results reveal that the soil consists of $30 \%$ clay (Fig. 2). X-Ray Diffractometer (XRD) analysis was performed to know mineralogical contents of soil. This analysis was conducted on Riguku X-Ray Diffractometer having voltage and current of $35 \mathrm{kV}$ and $20 \mathrm{~mA}$ respectively. According to results (Table 1), the soil sample is made up of both non-clay and clay minerals. The major minerals present in the soil include quartz, feldspar, kaolinite, illite and montmorillonites. Several other properties of the soil were determined. These include Atterberg limits, Maximum Dry Density (MDD), Optimum Moisture Content (OMC), Activity, UCS and CBR (Table 1).

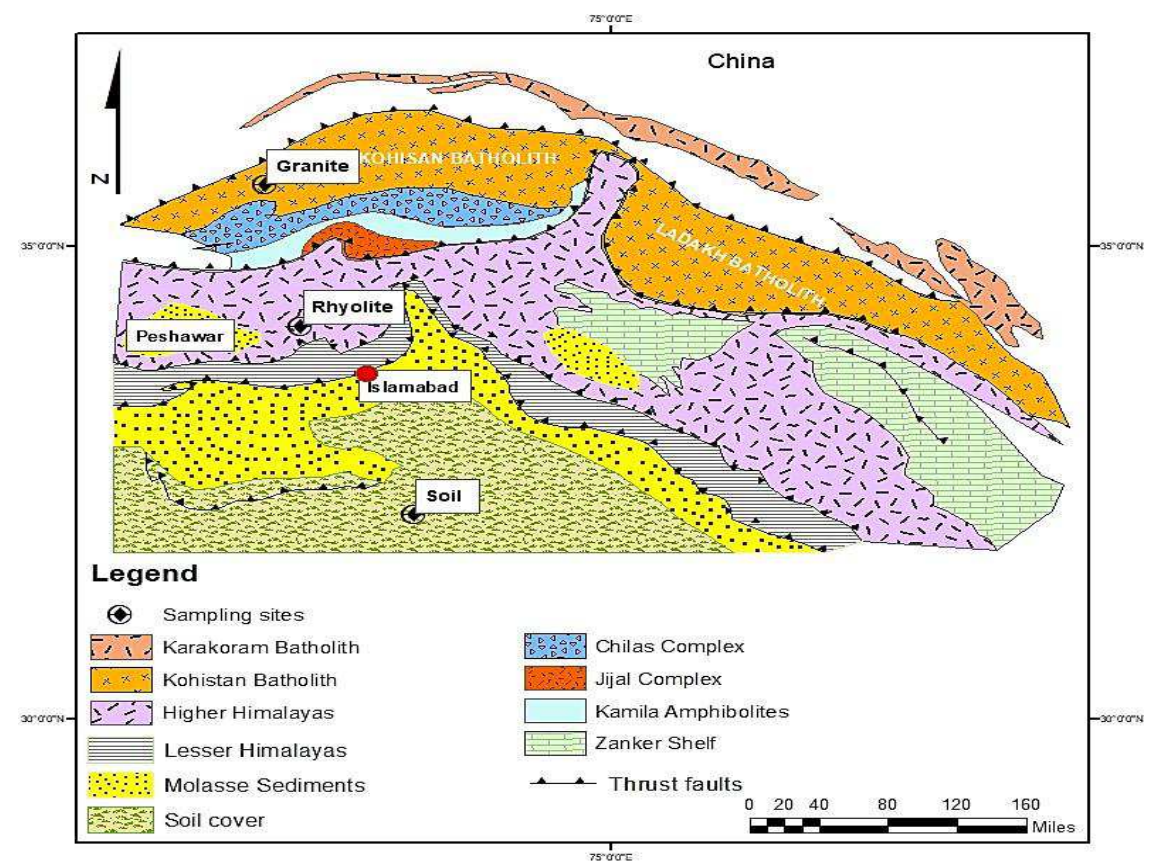

Fig. 1: Geological map [21] showing location of the rocks (granite and rhyolite) and soil samples used. 


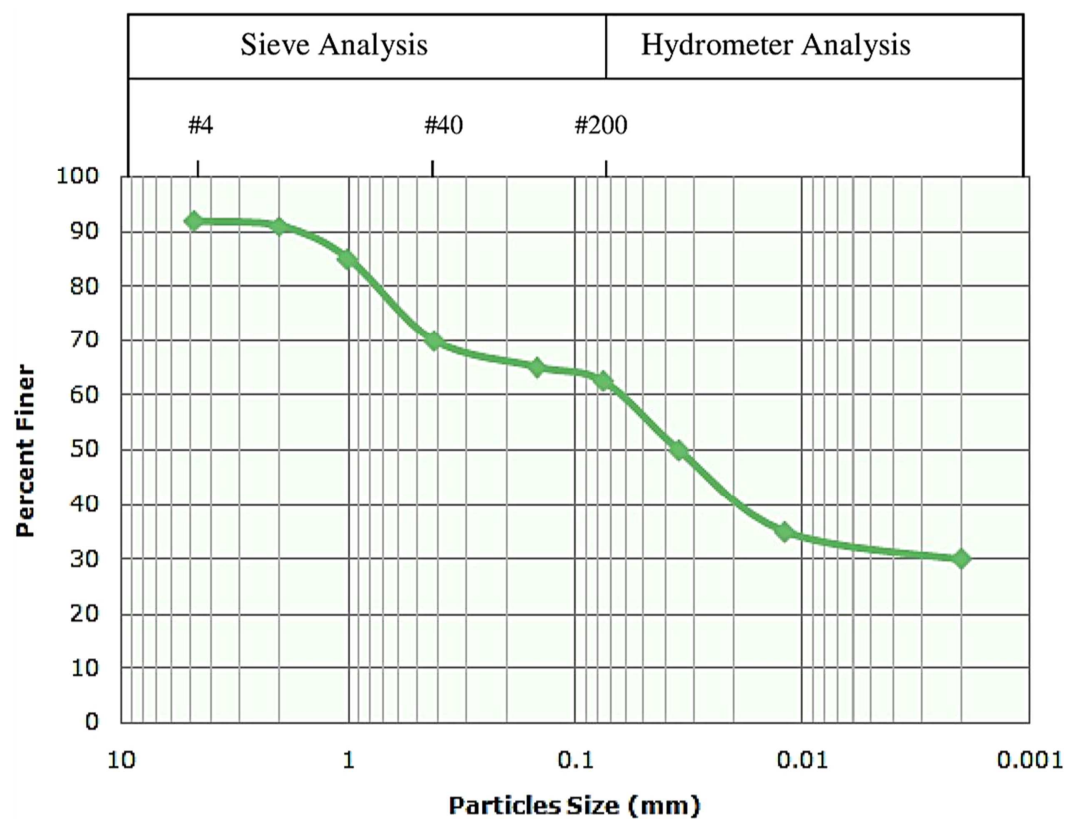

Fig. 2: Grain size distribution of the investigated soil sample.

Table 1: Geotechnical properties and mineralogy of untreated soil sample.

\begin{tabular}{|c|c|}
\hline Specific gravity & 2.49 \\
\hline MDD [kg/m ${ }^{3}$ ] & 1618.1 \\
\hline OMC [\%] & 25.1 \\
\hline Liquid limit [\%] & 57.9 \\
\hline Plastic limit [\%] & 21.7 \\
\hline PI [\%] & 36.2 \\
\hline Activity & 1.20 \\
\hline CBR [\%] & 30 \\
\hline UCS [kPa] & 37 \\
\hline Quartz [\%] & 46 \\
\hline Feldspar [\%] & 12 \\
\hline Kaolinite [\%] & 22 \\
\hline Illite [\%] & 12 \\
\hline Montmorillonite [\%] & 8 \\
\hline
\end{tabular}

\subsection{Lime}

Quick lime, obtained from a local market in Abbottabad KPK, was used in this study. Its physical parameters and chemical composition are listed in Table 2.

Table 2: Chemical composition and physical properties of lime.

\begin{tabular}{|c|c|}
\hline $\mathrm{Fe}_{2} \mathrm{O}_{3}[\%]$ & 0.77 \\
\hline Cao [\%] & 92.2 \\
\hline MgO [\%] & 1.1 \\
\hline $\mathrm{SO}_{3}[\%]$ & 5.93 \\
\hline Specific gravity & 2.2 \\
\hline Fineness $\left[\mathrm{cm}^{2} / \mathrm{g}\right]$ & 3994 \\
\hline
\end{tabular}




\subsection{Rock samples}

Two different types of igneous rocks, namely granite and rhyolite, were used as stabilizing agent. The rhyolite sample was collected from Swabi, KPK (Fig. 1). The rhyolite exposure is mostly jointed due to either brittle deformation or contraction on cooling; however massive (intact) portions with light to dark grey colour also occur at places. The sample of granite was picked from Kohistan Batholith in Kumrat Valley, KPK (Fig. 1). Texturally, the granite is sub-equigranular to inequigranular, hypidiomorphic, massive, i.e. without any preferred orientation of mineral grains. Experimental tests were performed on both the rock samples for the purpose of determining their geotechnical and mineralogical properties. The geotechnical properties, determined in accordance with the ASTM D7012 [22] and ASTM D6473 [23] respectively, include UCS, specific gravity and water absorption (Table 3). The mineralogical make-ups of the granite and rhyolite were determined using standard rock thin sections under transmitted light polarizing microscope. The studies reveal that the granite consists of orthoclase, plagioclase, quartz, biotite and muscovite (Table 3), while the rhyolite is composed predominantly of quartz, minor amounts of plagioclase, alkali feldspar, sphene, epidote and tourmaline (Table 3). More or less similar mineralogical compositions were also documented by Arif et al. [24] and Nawaz et al. [25] based on their studies on granite and rhyolite from the same areas (Fig. 4). A comparison of the geotechnical properties of the two rocks and their dependence on quartz to feldspars ratio are also illustrated (Fig. 3). Following crushing and grinding, the two rock samples were passed through sieve \#40 to obtain fine powder.

Table 3: Modal mineralogical composition, strength and physical properties of rocks.

\begin{tabular}{|c|c|c|}
\hline Sample & Granite & Rhyolite \\
\hline Quartz [\%] & 42.4 & 66 \\
\hline Alkali feldspar [\%] & 33.2 & 15.1 \\
\hline Plagioclase [\%] & 6.1 & 10.3 \\
\hline Sphene [\%] & ---- & 4.7 \\
\hline Epidote [\%] & ---- & 0.38 \\
\hline Biotite [\%] & 15.2 & ---- \\
\hline Tourmaline [\%] & --- & 3.12 \\
\hline Opaque(s) [\%] & 3.1 & 0.4 \\
\hline Quartz to feldspar ratio & 1.08 & 2.60 \\
\hline Water absorption [\%] & 0.94 & 0.68 \\
\hline UCS [MPa] & 61.9 & 65.2 \\
\hline Specific gravity & 2.71 & 2.74 \\
\hline
\end{tabular}

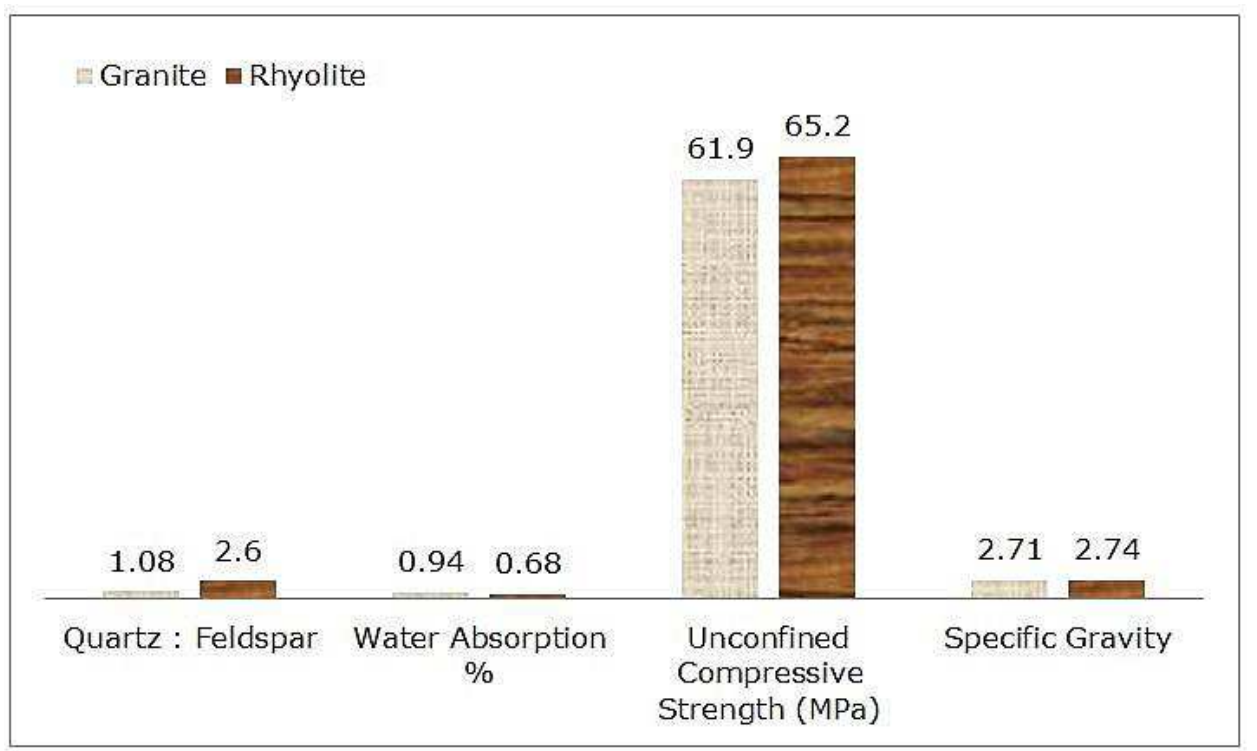

Fig. 3: Geotechnical parameters of the used rock samples. 

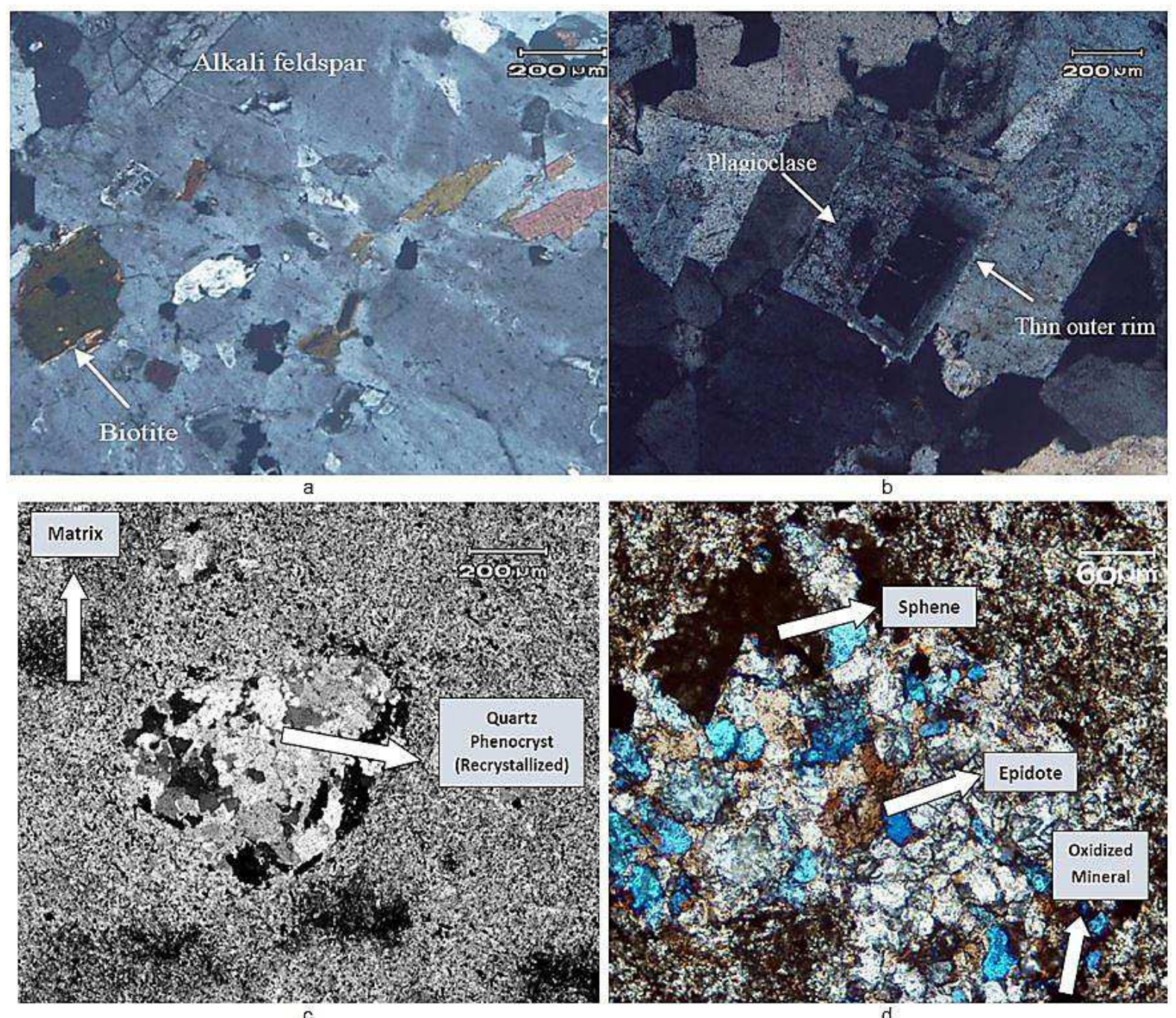

Fig. 4: Photomicrographs representing the granite $(a, b)$ and rhyolite $(c, d)$ samples [24, 25].

\section{Methods}

\subsection{Initial Consumption of Lime (ICL)}

The ICL test provides details regarding minimum quantity of lime that is enough to produce stabilization reactions between lime and soil. For the occurrence of these reactions, it is necessary for the mixture of clay and lime to have a pH more than 12.40. The lime content that can increase the soil $\mathrm{pH}$ from 12.40 is considered ideal for clay stabilization. This causes dissolution of aluminous and siliceous compounds from clay soil, which react with calcium ions of lime in pore solution to produce calcium silicate hydrate and calcium aluminium hydrate that coat the soil particles and force them to bind together. In case of the present study, the ICL test was conducted according to the BS1994 (1990) [26]. Addition of $3 \%$ lime yields $\mathrm{pH}$ value of 12.41 that marks commencement of the stabilization reactions, while $6 \%$ lime addition gives a pH value of 12.71 , which is the most significant to stabilize the soil. Addition of lime beyond $6 \%$ does affect the soil pH but insignificantly (Fig. 5). 


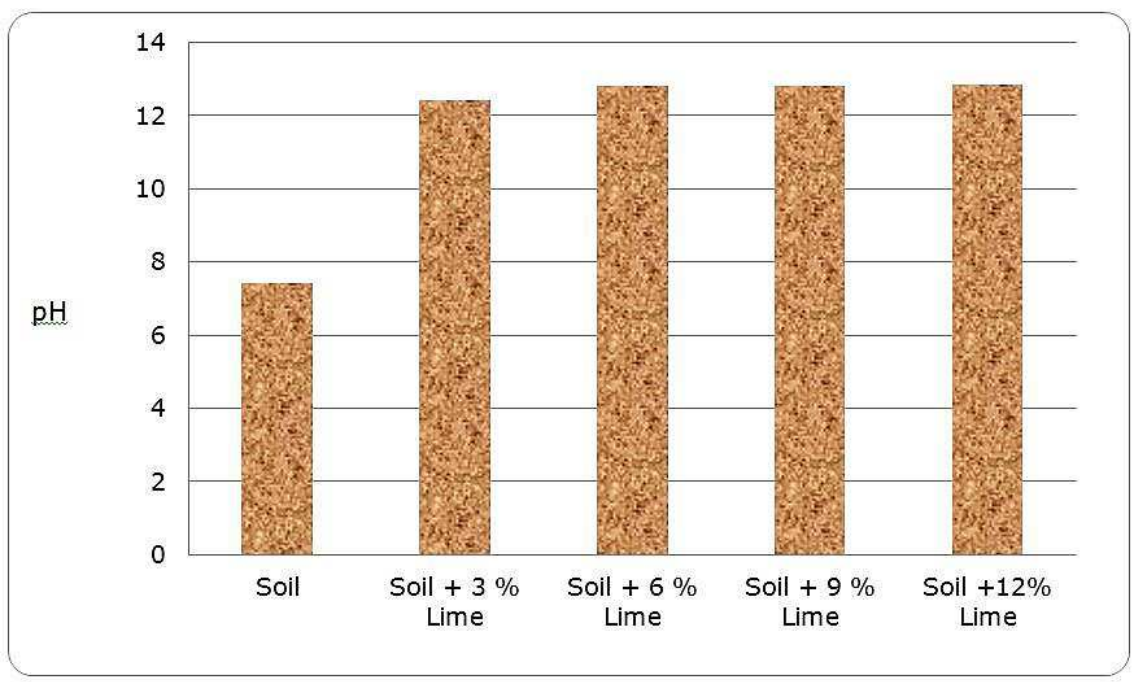

Fig. 5: Variation in the $\mathrm{pH}$ of soil through lime addition.

\subsection{Samples preparation}

Initially four samples of the collected soil were prepared by adding lime to dry soil mass in different proportions, i.e. $3 \%, 6 \%, 9 \%$ and $12 \%$ (Table 4). Each of the resulting samples was mixed by following the criteria used by Geremew and Mamuye [27] and then subjected to a series of laboratory determinations including Atterberg limit, standard proctor compaction, UCS and CBR. The sample with the most effective lime percentage i.e. $6 \%$ was selected for further stabilization with the two rock powders. Eight more samples were prepared from the soil sample with $6 \%$ lime by adding to it granite and rhyolite powders in different proportions (Table 5). All the tests, mentioned above, were applied to each one of the eight samples and Activity values of all the eight samples were calculated as follows: Activity = Plasticity index/Clay content [28].

Table 4: Detail of the soil samples preparation with lime.

\begin{tabular}{|c|c|}
\hline Sample No. & Details \\
\hline 1 & soil $+03 \%$ lime \\
\hline 2 & soil $+06 \%$ lime \\
\hline 3 & soil $+09 \%$ lime \\
\hline 4 & soil $+12 \%$ lime \\
\hline
\end{tabular}

\subsection{Atterberg limits}

The Atterberg limits including Liquid limit, Plastic limit and PI were determined by using the method described in ASTM D4318 [29]. The changes caused by lime, granite powder and rhyolite powders on these limits were then studied. The liquid and plastic limits were determined at standard room temperature, while the plasticity index was obtained by subtracting the value of plastic limit from liquid limit.

\subsection{Proctor compaction test}

The standard proctor compaction test was carried out in accordance with the ASTM D698 method [30]. These tests conducted for determining the values of MDD and OMC of the untreated (original) soil as well as all the treated soil samples.

\subsection{California Bearing Ratio (CBR) and Unconfined Compressive Strength (UCS) test}

An authentic knowledge of the values of CBR and UCS tests is very important for designing structures. They are used to evaluate the strength of soils. The CBR test was performed by using the ASTM D1883 method [31], whereas UCS was determined by using the method given in ASTM D2166 [32]. 
Table 5: Detail of the sample preparation with addition of lime, granite and rhyolite powder.

\begin{tabular}{|c|c|}
\hline Sample No. & Details \\
\hline 1 & soil $+6 \%$ lime $+08 \%$ granite powder \\
\hline 2 & soil $+6 \%$ lime $+16 \%$ granite powder \\
\hline 3 & soil $+6 \%$ lime $+24 \%$ granite powder \\
\hline 4 & soil $+6 \%$ lime $+32 \%$ granite powder \\
\hline 5 & soil $+6 \%$ lime $+08 \%$ rhyolite powder \\
\hline 6 & soil $+6 \%$ lime $+16 \%$ rhyolite powder \\
\hline 7 & soil $+6 \%$ lime $+24 \%$ rhyolite powder \\
\hline 8 & soil $+6 \%$ lime $+32 \%$ rhyolite powder \\
\hline
\end{tabular}

\section{Results and discussion}

\subsection{Atterberg limits and Activity}

The results of Atterberg limits and Activity determinations on samples containing different proportions of the original soil, lime, granite and rhyolite powders are shown in Tables 6 and 7. The changes in Plasticity index with the addition of the mentioned admixtures are shown in Fig. 6 . The reduction in $\mathrm{PI}$ and Activity indicates improvement in the soil in terms of its strength and workability. The chances of compression and swelling are always higher in the high PI soils due to their tendency to absorb larger quantities of water [33]. The value of PI in the studied soil is high due to the presence of clay minerals including kaolinite, illite and montmorillonites (Table 1) and that is why the soil sample is characterized as $\mathrm{CH}$ class clay according to the Unified Soil Classification System (Fig. 7). Significant reduction in $\mathrm{PI}$ and Activity is observed with the addition of $6 \%$ lime to enhance the workability and strength of soils. The addition of $6 \%$ lime reduces the PI and Activity from 36.2 to 22.82 and 1.20 to 0.76 respectively. Increasing the percentage of lime beyond $6 \%$ produces very minute effect on the values of $\mathrm{PI}$ and Activity due to insignificant increase in $\mathrm{pH}$ (Table 6, Fig.5). That is why only $6 \%$ of lime content in soil was chosen for further stabilization with igneous rock powders. A similar behaviour was noticed also by Harichane et al. [34] and Al-Swaidani et al. [7]. According to Swaidani et al. [7], mixing of lime in clay soil causes dissociation of $\mathrm{Ca}^{2+}$ and $\mathrm{OH}^{1-}$ ions into pore solution, and hence $\mathrm{pH}$ of the pore solution is increased. This phenomenon creates favourable environment for the exchange of $\mathrm{Ca}^{2+}$ ions present in the lime with the monovalent ions existing in the diffused double layer (DDL) of negatively charged soil minerals. This exchange causes reduction in thickness of the DDL and flocculation-agglomeration of clay particles. As a result, the Plasticity index falls instantly, which is a key sign of improvement in soil workability and strength.

The addition of granite and rhyolite powders causes significant reduction in the PI and Activity of the lime stabilized soil further. The addition of granite powder reduced the values of PI and Activity from $22.82 \%$ to 1.4 and 0.76 to 0.04 respectively, while the rhyolite powder decreased PI and Activity from $22.82 \%$ to 0.8 and 0.76 to 0.02 respectively. Both the parameters decrease regularly with gradual increase in the amount of rock powders until their values become minimum with the addition of $32 \%$ rock powder (Table 7 and Fig. 6). The principal reason for sufficient reduction in PI and Activity is the presence of quartz in the added granite and rhyolite powders (Table 3, Figs. 3 and 4). The activity value of quartz is zero, due to which quartz is non-cohesive and cannot absorb a larger amount of water [35]. That is why the water absorption capacity of both the rock samples is less than 1 (Table 3). The addition of rock powders consisting of such non-cohesive and less hydrophilic minerals to a lime-stabilized soil is expected to enhance the workability of soil by reducing its $\mathrm{PI}$ and Activity both to significantly low levels (Table 7). Such an improvement is not possible through stabilization of soil by the use of lime only. These results strongly indicate suitability of granite and rhyolite powders for enhancing the workability and strength of lime stabilized soils.

Table 6: Detail of the treatment process of soil with lime and properties of the resulting samples.

\begin{tabular}{|c|c|c|c|c|c|c|c|c|c|}
\hline Sample No. & Description & $\operatorname{MDD}\left[\mathrm{kg} / \mathrm{m}^{3}\right]$ & OMC [\%] & LL [\%] & PL [\%] & PI [\%] & CBR [\%] & Activity & UCS [kPa] \\
\hline 1 & soil + $03 \%$ lime & 1578.52 & 26.4 & 54.12 & 22.11 & 32.01 & 40.0 & 1.06 & 47 \\
\hline 2 & soil + $06 \%$ lime & 1518.35 & 28.3 & 47.12 & 24.3 & 22.82 & 51.8 & 0.76 & 63 \\
\hline 3 & soil + $09 \%$ lime & 1449.01 & 30.7 & 46.80 & 24.1 & 22.70 & 55.0 & 0.75 & 66 \\
\hline 4 & soil + $12 \%$ lime & 1468.39 & 32.4 & 46.10 & 23.9 & 22.20 & 59.0 & 0.74 & 70 \\
\hline
\end{tabular}


Table 7: Detail of the treatment process of lime stabilized soil with rhyolite and granite powders and properties of the resulting samples.

\begin{tabular}{|c|c|c|c|c|c|c|c|c|c|}
\hline Sample No. & Description & $\begin{array}{l}\text { MDD } \\
\mathrm{kg} / \mathrm{m}^{3}\end{array}$ & $\begin{array}{c}\text { OMC } \\
\text { [\%] }\end{array}$ & $\begin{array}{l}\text { LL } \\
\text { [\%] }\end{array}$ & $\begin{array}{l}\text { PL } \\
{[\%]}\end{array}$ & $\begin{array}{c}\mathrm{PI} \\
{[\%]}\end{array}$ & $\begin{array}{c}\text { CBR } \\
{[\%]}\end{array}$ & $\begin{array}{l}\text { Acti- } \\
\text { vity }\end{array}$ & $\begin{array}{c}\text { UCS } \\
{[\mathrm{kPa}]}\end{array}$ \\
\hline 1 & soil $+6 \%$ lime $+08 \%$ granite powder & 1606.09 & 26.21 & 43.1 & 25.4 & 18.3 & 60.7 & 0.61 & 71 \\
\hline 2 & soil $+6 \%$ lime $+16 \%$ granite powder & 1678.45 & 23.2 & 38.5 & 26.42 & 12.0 & 70.1 & 0.4 & 79 \\
\hline 3 & soil $+6 \%$ lime $+24 \%$ granite powder & 1748.81 & 21.1 & 33.1 & 27.11 & 5.99 & 78.4 & 0.19 & 88 \\
\hline 4 & soil $+6 \%$ lime $+32 \%$ granite powder & 1838.55 & 18.9 & 29.3 & 27.9 & 1.4 & 85.5 & 0.04 & 97 \\
\hline 5 & soil $+6 \%$ lime $+8 \%$ rhyolite powder & 1648.88 & 25.3 & 42.9 & 25.1 & 17.8 & 61.8 & 0.59 & 72 \\
\hline 6 & soil $+6 \%$ lime $+16 \%$ rhyolite powder & 1708.02 & 22.1 & 37.6 & 26.2 & 11.4 & 71.9 & 0.38 & 81 \\
\hline 7 & soil $+6 \%$ lime $+24 \%$ rhyolite powder & 1848.74 & 18.6 & 32.3 & 26.9 & 5.4 & 81.2 & 0.18 & 92 \\
\hline 8 & soil $+6 \%$ lime $+32 \%$ rhyolite powder & 1957.85 & 17.1 & 28.4 & 27.6 & 0.8 & 90.7 & 0.02 & 102 \\
\hline
\end{tabular}

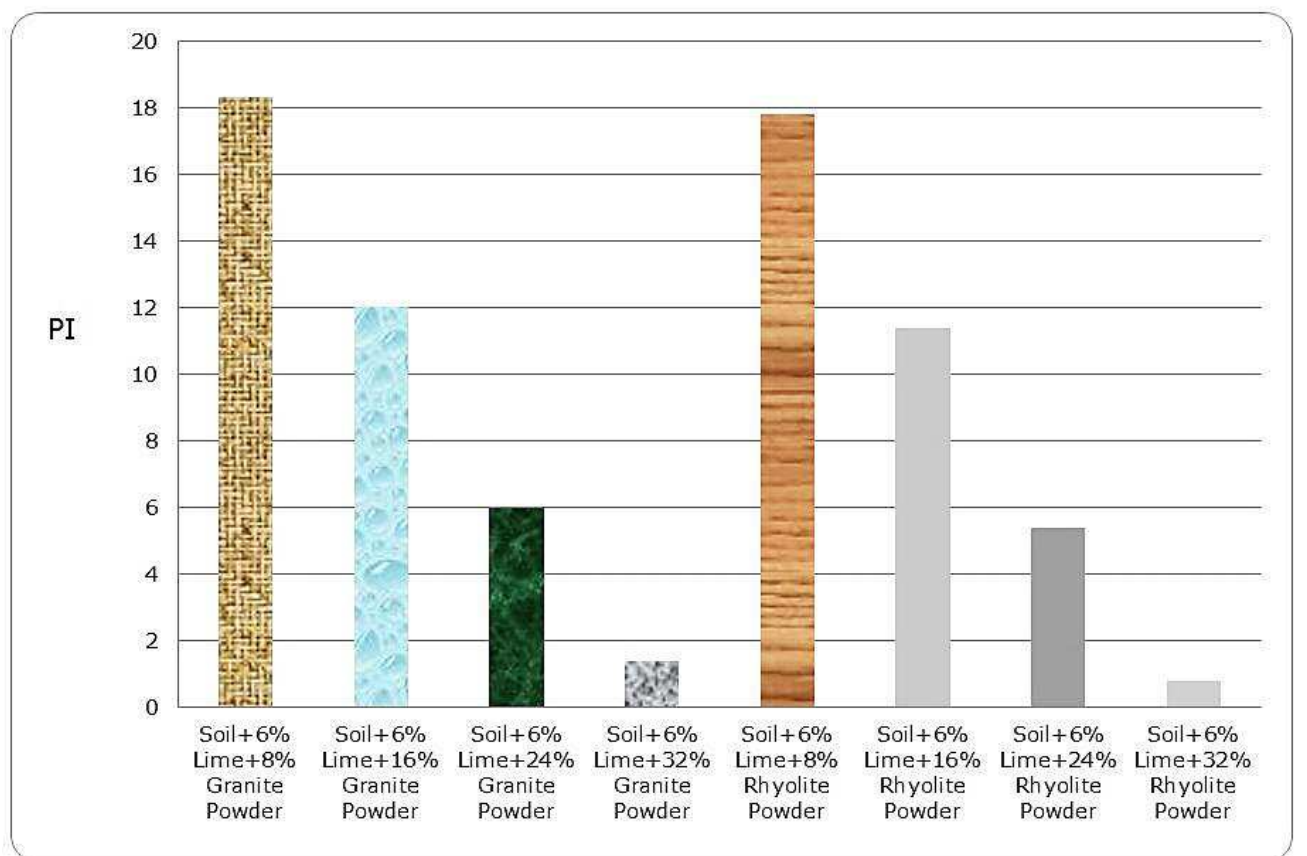

Fig. 6: Variation in the plasticity index of lime-stabilized soil containing different proportions of granite and rhyolite powder.

\subsection{Compaction properties}

The standard proctor compaction test was employed to assess the effect of lime. Granite and rhyolite powders were then added to see their impact on OMC and MDD of the previously limestabilized soil sample. Table 6 illustrates that the addition of $6 \%$ lime has increased the percentage of OMC and reduced the MDD of the treated soil from $25.1 \%$ to $28.3 \%$ and $1618 \mathrm{~kg} \cdot \mathrm{m}^{-3}$ to $1518 \mathrm{~kg} \cdot \mathrm{m}^{-3}$ respectively. However, this improvement is not good enough and hence lime alone cannot stabilize weak soils adequately. Similar results were obtained also by Bell [9], Al-Swaidani et al. [7] and Manasseh and Olufemi [36]. The observed increase in OMC and reduction in MDD are mainly because specific gravity of the added lime (2.20; Table 2) is lower than that of the original soil (2.49; Table 1). Another possible reason for these adverse changes is that addition of lime leads to aggregation of particles to cover the spaces by disturbing effective soil grading [7].

Adding of granite and rhyolite powders as an admixture to soil already stabilized with $6 \%$ lime decreases OMC and increases MDD. The overall impact of the two rock powders on the compaction properties of lime stabilized soils is shown in Fig. 8 and Table 7. The addition of $32 \%$ granite and rhyolite powders reduced the values of OMC from $28.3 \%$ to $18.9 \%$ and $17.1 \%$ respectively. On the other hand, addition of the granite and rhyolite powder enhances the values of MDD from $1518 \mathrm{~kg} \cdot \mathrm{m}^{-3}$ to $1838 \mathrm{~kg} \cdot \mathrm{m}^{-3}$ and $1957 \mathrm{~kg} \cdot \mathrm{m}^{-3}$ respectively. The higher specific gravity of granite and rhyolite powders (Table 3 ) and their low affinity with water are the key reasons for this positive development. The betterment in compaction properties is a good sign of improvement in the bearing capacity of the soil. 


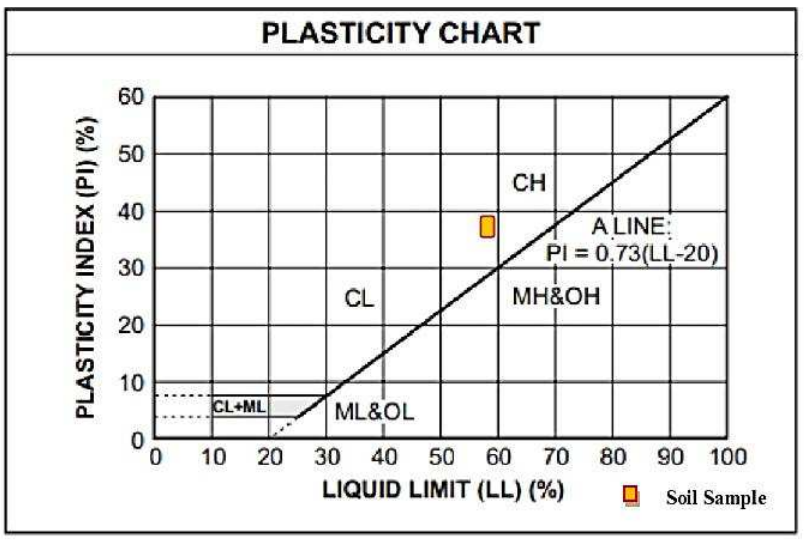

Fig. 7: Categorization of soil sample by using unified soil classification system.

\subsection{California Bearing Ratio (CBR) and Unconfined Compressive Strength (UCS)}

CBR refers to the determination of subgrade bearing capacity of soil for use in road construction while UCS is directly related to the overall strength of the soil. These two are the most important parameters since they play a significant role in the selection of a given material. Higher the CBR and UCS values, higher are going to be the strength. The effect of lime on CBR and UCS values of the studied soil is shown in Table 6. The increase in the CBR and UCS values is probably because of creation of cementitious compounds through reaction between clay minerals in the soil and the added lime.

The addition of granite and rhyolite powders improves quality of the lime stabilized soil further (Table 7 and Fig. 8). Up to $32 \%$ addition of either the granite or rhyolite powder enhances the values of both the CBR (from $51.8 \%$ to $85.5 \%$ and $90.7 \%$, respectively) and UCS (from $63 \mathrm{kPa}$ to $97 \mathrm{kPa}$ and $102 \mathrm{kPa}$, respectively). The enhancement in CBR and UCS values is attributed to the higher MDD of the added rock powders that lead to a reduction in soil porosity.

Both the rock powders improve the properties of lime stabilized clays to significant levels. However, the effect produced by rhyolite is relatively greater than granite. This difference can be explained by comparing the texture and/ or modal mineralogy of the two samples. The most significant of the texture-related rock features affecting geotechnical properties is grain size. However, the difference regarding texture especially grain size is largely eliminated since only fine-grained fractions of both the varieties were used. Therefore, the difference in the relative influence of granite and rhyolite on soil reflects differences in their modal mineralogical compositions. As listed in Table 3, the rhyolite sample contains a larger amount of quartz and smaller amounts of feldspars and mafic minerals than granite. The most important mineralogical parameter in terms of rock geotechnical properties is the quartz to feldspars ratio. The better properties of rhyolite (higher specific gravity, UCS and lower water absorption value) than granite are thus due to the much higher quartz to feldspars ratio of the former than the latter. That is also why rhyolite is more effective in stabilizing the soil than granite.

$$
\operatorname{OMC}(\%) \text { aUCS (KPA) }=\mathrm{CBR}(\%)
$$

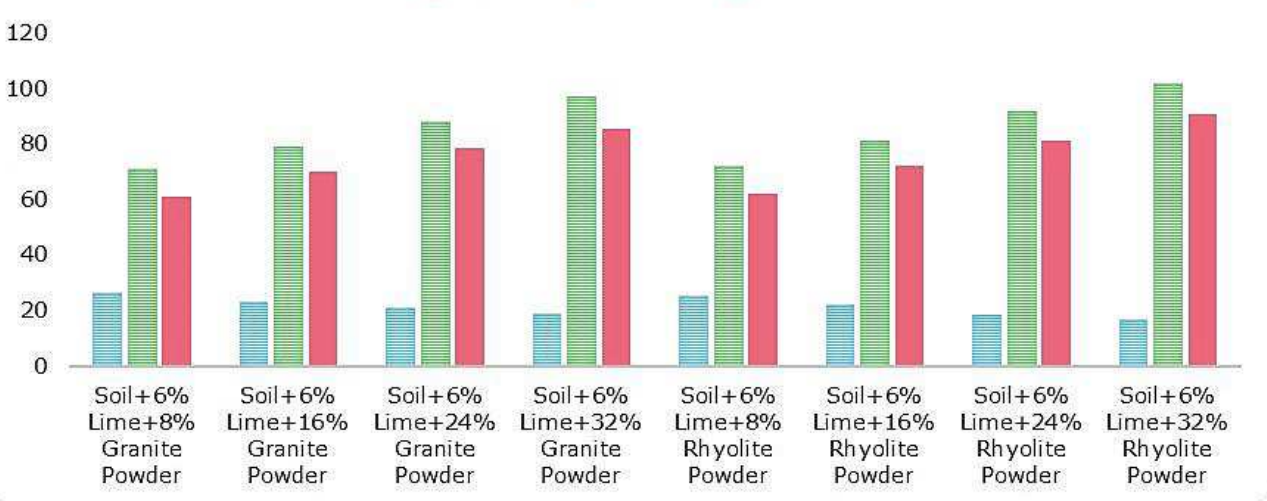

Fig. 8: Variation in OMC, CBR and UCS of lime-stabilized soil containing different proportions of granite and rhyolite powders. 


\section{Conclusions}

The addition of up to $32 \%$ granite and rhyolites powders appreciably improves the performance of lime-stabilized clays in the given ways:

1. Escalating MDD, UCS and CBR.

2. Noticeably reducing $\mathrm{PI}$ and Activity: reduction in both signifies increase in strength.

3. Compensating the drop in soil MDD and rise in OMC caused by addition of lime.

Furthermore, the relative impact of granite and rhyolite on the soil properties is different because of the difference in their mineralogical composition

\section{References}

[1] SECO, A. - RAMÍREZ, F. - MIQUELEIZ, L. - GARCÍA, B.: Stabilization of expansive soils for use in construction. Applied Clay Science, Vol. 51, 2011, pp. 348-352.

[2] BUHLER, R. L. -CERATO, A. B.: Stabilization of Oklahoma expansive soils using lime and class C fly ash. ASCE Geotechnical Special Publication, Vol. 162, 2007, pp. 1-10.

[3] GILLOTT, J. E. - PENNER, E. - EDEN, W. J.: Microstructure of Billings shale and biochemical alteration products. Ottawa Ontario, Vol. 3, No. 11, 1974, pp. 482-489.

[4] CALDWELL, J. A. - SMITH, A. - WAGNER, J.: Heave of coal shale fill. Canadian Geotechnical Journal, Vol. 21, 1984, pp. 379-383.

[5] SAKR, M. A. - SHAHIN, M. A. - METWALLY, Y. M.: Utilization of lime for stabilization soft clay soil of high organic content. Geotechnical and Geological Engineering, Vol. 27, 2009, pp. 105-113.

[6] ANU, K. - GURUNG, D. - YADAV, R. - LOLLEN, L - BHUTIA, N. P.: Stabilization of soft clay soil using Fly ash and Limestone dust. International Journal of Scientific and Engineering Research, Vol. 7, No. 5, 2016, pp. 18-22.

[7] AL-SWAIDANI, A. - HAMMOUD, I. - MEZIAB, A.: Effect of adding natural pozzolana on geotechnical properties of lime-stabilized clayey soil. Journal of Rock Mechanics and Geotechnical Engineering, Vol.8, 2016, pp. 714-725.

[8] ROGERS, C. - GLENDINNING, S.: Modification of clay soils using lime. Proceedings of the seminar at Loughborough University, UK, 1996, pp. 99-114.

[9] BELL, F. G.: Lime stabilization of clay minerals and soils. Engineering Geology Journal, Vol. 42, No. 4, 1996, pp. 223-237.

[10] THOMPSON, M. R.: Split-tensile strength of lime-stabilized soils. Highway Research Record, Vol. 92, 1965, pp. 69-82.

[11] KASSIM, K. A. - CHERN, K. K.: Lime stabilized Malaysian cohesive soils. Journal Kejuruteraan Awan, Vol. 16, 2014, pp. 13-23.

[12] RAO, S. M. - SHIVANANDA, P.: Compressibility behavior of lime-stabilized clay. Geotechnical and Geological Engineering, Vol. 23, 2005, pp. 309-319.

[13] CALIK, U. - EROL, S.: Classification, shear strength, and durability of expansive clayey soil stabilized with lime and perlite. Natural Hazards, Vol. 7, No. 3, 2014, pp. 1289-1303.

[14] CONSOLI, N. C - PRIETTO, P. D. M - DA SILVA LOPES, L - WINTER, D.: Control factors for the long term compressive strength of lime treated sandy clay soil. Transportation Geotechnics, Vol. 1, No. 3, 2014, pp. 129-136.

[15] GHOBADI, M. H. - ABDILOR, Y - BABAZADEH, R.: Stabilization of clay soils using lime and effect of $\mathrm{pH}$ variations on shear strength parameters. Bulletin of Engineering Geology and the Environment, Vol. 73, No. 2, 2014, pp. 611-619.

[16] NEGAWO, W. J. - DI EMIDIO, G. - BEZUIJEN, A. - VERASTEGUI FLORES, R. D. - FRANCOIS, B.: Lime stabilisation of high plasticity swelling clay from Ethiopia. European Journal of Environmental and Civil Engineering, Vol. 23, No. 4, 2017, pp. 504-514.

[17] BASMA, A. A. - TUNCER, E. R.: Effect of lime on volume change and compressibility of expansive clays, Transportation Research Record, Vol. 1296, 1991, pp. 54-61.

[18] KHALID, N. - ARSHAD, M. - MUKRI. - MAZIDAH. - KAMARUDIN. - FAIZAH. - GHANI, A.: The California bearing ratio (CBR) value for banting soft soil subgrade stabilized using lime-pofa mixtures. Electronic Journal of Geotechnical Engineering, Vol. 19, 2014, pp. 155-163.

[19] SAEED, K, A.: The Strength Behaviour of Lime Stabilized Organic Clay Soil Modified by Catalyst Additives. Journal of Babylon University/Engineering Sciences, Vol. 24, 2016, pp. 201-1064

[20] ASTM D7928-17.: Standard Test Method for Particle-Size Distribution (Gradation) of FineGrained Soils Using the Sedimentation (Hydrometer) Analysis. ASTM International, West Conshohocken, PA, USA, 2017. 
[21] SEARLE, M. P. - TRELOAR, P. J.: Was Late Cretaceous-Paleoceneobduction of ophiolite complexes the primary cause of crustal thickening and regional metamorphism in the Pakistan Himalaya. Geological Society, London, Special Publications, Vol. 338, 2010, pp. 345-359.

[22] ASTM D7012-14e1.: Standard Test Methods for Compressive Strength and Elastic Moduli of Intact Rock Core Specimens under Varying States of Stress and Temperatures. ASTM International, West Conshohocken, PA, USA, 2014.

[23] ASTM D6473-15.: Standard Test Method for Specific Gravity and Absorption of Rock for Erosion Control. ASTM International, West Conshohocken, PA, USA, 2015.

[24] ARIF, M. - ISLAM, I. - RIZWAN, M.: Petrography and physico-mechanical properties of the granitic rocks from Kumrat valley, Kohistan Batholith, NW Pakistan. AshEse Journal of Physical Science, Vol. 1, No. 1, 2015, pp. 1-8.

[25] NAWAZ, A. - IMRAN, M. - SHAH, D. S.: Petrography and Physico-mechanical properties of Rhyolites from Gohati area of Swabi NW Pakistan. Unpublished thesis, Peshawar University, 2013, p73.

[26] BS 1924: Stabilized materials for civil engineering purposes. London, UK: British Standards Institute; 1990.

[27] GEREMEW, A. - MAMUYE, Y.: Improving the Properties of Clay Soil by Using Laterite Soil for Production of Bricks. Civil and Environmental Engineering, Vol. 15. No. 2, 2019, pp. 134-141.

[28] SKEMPTON, A. W.: A possible relationship between true cohesion and the mineralogy of clays. Proceedings of the second International Conference, Rotterdam, Vol. 7, 1948, pp. 45-46.

[29] ASTM D4318.: Standard test methods for liquid limit, plastic limit and plasticity index of soils. ASTM International, West Conshohocken, PA, USA, 2000.

[30] ASTM D698.: Standard test method for laboratory compaction characteristics of soil using standard effort. ASTM International, West Conshohocken, PA, USA, 2000.

[31] ASTM D1883.: Standard test method for CBR (California bearing ratio) of laboratory compacted soils. ASTM International, West Conshohocken, PA, USA, 1999.

[32] ASTM D2166-06.: Standard Test Method for Unconfined Compressive Strength of Cohesive Soil. ASTM International, West Conshohocken, PA, USA, 2006.

[33] RAO, S. M.: Identification and classification of expansive soils. Recent advances in characterization and treatment, Taylor and Francis Group, 2006, pp.15-24.

[34] HARICHANE, K. - GHRICI, M. - KENAI, S - GRINE, K.: Use of natural pozzolana and lime for stabilization of cohesive soils. Geotechnical and Geological Engineering, Vol. 29, No. 5, 2011, pp. 759-769.

[35] RAJARAMAN, J. - THIRUVENKATASAMY, K.: The Dependence of Coaxial and Non-Coaxial Components of Shear Strength of Clays on Activity and Environment in Lowlands. International Conference on Environment Science and Engineering, Singapore, Vol. 3, 2012, pp. 73-78.

[36] MANASSEH, J. - OLUFEMI, A.: Effect of lime on some geotechnical properties of Igumale shale. Electronic Journal of Geotechnical Engineering, Vol. 13, No. 5, 2008, pp. 1-9. 